\title{
PENGARUH INFLASI, BI 7 DAY REPO RATE DAN NILAI TUKAR TERHADAP MARGIN PEMBIAYAAN MURABAHAH PERBANKAN SYARIAH
}

\author{
Ekawati Ramadhani ${ }^{\star}$ \\ Universitas Islam Negeri Maulana Malik Ibrahim Malang \\ Guntur Kusuma Wardana \\ Universitas Islam Negeri Maulana Malik Ibrahim Malang
}

\begin{abstract}
The purpose of this study was to determine the effect of inflation, the $\mathrm{BI} 7$ Day Repo Rate, and the exchange rate on the murabahah financing margin partially and simultaneously for Islamic banking in Indonesia for the 20162020 period. The method used is quantitative research with a descriptive approach. The sampling technique used purposive sampling with a total sample of 2 research samples. The results show that partially the inflation and exchange rate variables have a significant negative effect on the murabahah financing margin, while the $\mathrm{BI} 7$ day repo rate variable has no effect on the murabahah financing margin in Islamic banking in Indonesia. Simultaneously, the results of the research show that inflation variables, $\mathrm{BI}$ 7 Day Repo Rate, and exchange rates have a significant effect on the margin of murabahah financing.
\end{abstract}

Keywords: Inflation, BI 7 Day Repo Rate, Exchange Rate, Murabahah Financing Margin..

Paper type: Research paper

*Corresponding author: ekawatiramadhani14@gmail.com

Received: September 02, 2021; Accepted: November 13, 2021; Available online: December, 06, 2021

Cite this document:

Ramadhani, E., \& Wardana, G. K. (2021). Pengaruh Inflasi, Bi 7 Day Repo Rate dan Nilai Tukar Terhadap Margin Pembiayaan Murabahah Perbankan Syariah. Jurnal Masharif Al-Syariah: Jurnal Ekonomi dan Perbankan Syariah, 6(3), 787802. doi:http://dx.doi.org/10.30651/jms.v6i3.9755

Copyright (C) 2021, Jurnal Masharif Al-Syariah: Jurnal Ekonomi dan Perbankan Syariah http://journal.um-surabaya.ac.id/index.php/Mas/index

This article is licensed under a Creative Commons Attribution-NonCommercial 4.0 International License. 


\section{Abstrak}

Tujuan penelitian ini untuk mengetahui pengaruh inflasi, BI 7 Day Repo Rate, dan nilai tukar terhadap margin pembiayaan murabahah secara parsial dan simultan perbankan syariah di Indonesia periode 2016-2020. Adapun metode yang digunakan adalah penelitian kuantitatif dengan pendekatan deskriptif. Teknik pengambilan sampel menggunakan purposive sampling dengan jumlah sampel sebanyak 2 sampel penelitian. Hasil penelitian menunjukkan bahwa secara parsial variabel inflasi dan nilai tukar berpengaruh signifikan negatif terhadap margin pembiayaan murabahah, sedangkan variabel $\mathrm{BI} 7$ day repo rate tidak berpengaruh terhadap margin pembiayaan murabahah di perbankan syariah di Indonesia. Adapun hasil penelitian secara simultan, variabel inflasi, BI 7 Day Repo Rate, dan nilai tukar berpengaruh signifikan terhadap margin pembiayaan murabahah.

Kata kunci: Inflasi, BI 7 Day Repo Rate, Nilai Tukar, Margin Pembiayaan Murabahah.

\section{PENDAHULUAN}

Perbankan syariah mulai beroperasi pada tahun 1992 dikenal dengan nama Bank Muamalat Indonesia. Kegiatan perbankan syariah sesuai dengan Undang-Undang No.7 tahun 1992 yaitu pembiayaan penyertaan modal (musyarakah), prinsip bagi hasil (mudharabah), pembiayaan sewa murni (ijarah), dan jual beli barang (murabahah) (Utama, 2020). Krisis yang terjadi pada tahun 1998 menjadi pukulan besar bagi sistem keuangan Indonesia khususnya pada lembaga keuangan sektor perbankan konvensional. Pada saat terjadinya krisis, Bank Muamalat Indonesia menjadi satu-satunya lembaga keuangan yang mampu bertahan. Perbankan syariah memiliki perkembangan yang cukup bagus. Dilihat dari penelitian periode 2016-2020 menunjukkan bahwa perbankan syariah memiliki asset yang meningkat secara terus menerus (Anshori, 2009). Tahun 2016 total aset Rp. 356.504 T, 2017 total aset Rp. 424.181 T, 2018 total aset Rp. 477.327 T, 2019 total aset Rp. 524.564 T, dan 2020 total aset Rp. 571.177 T. Hal ini menunjukkan bahwa banyak masyarakat Indonesia 
yang menggunakan perbankan syariah dalam kegiatan penyaluran dana dan penempatan dana. Pada tahun 2020 Indonesia kembali mengalami krisis yang disebabkan oleh pandemi Covid-19, hal ini memiliki pengaruh besar terhadap sektor perbankan. Perbankan konvensional hanya mengalami pertumbuhan sebesar $7,77 \%$ sedangkan perbankan syariah mengalami pertumbuhan yang relatif tinggi sebesae $10,97 \%$.

Kegiatan perbankan syariah didominasi oleh pembiayaan murabahah. Hal ini sesuai data yang diperoleh yaitu pembiayaan murabahah dengan total 779,572 triliun, pembiayaan mudharabah total 73,881 triliun, pembiayaan musyarakah 642,033 triliun, pembiayaan qardh sebesar 34,950 triliun, dan pembiayaan ishtishna sebesar 8.158 triliun. Dominasi pembiayaan murabahah dapat mencapai $70-80 \%$ dari total keseluruahan pembiayaan pada perbankan syariah (Sjahdeni, 2014). pembiayaan murabahah banyak diminati oleh nasabah karena nasabah menganggap bahwa implementasi pembiayaan murabahah sama dengan sistem kredit perbankan syariah. Pernyataan tersebut sesuai dengan penelitian yang dilakukan oleh Wulandari et al., (2015) bahwa masyarakat masih menganggap perbankan syariah dengan perbankan konvensional adalah sama. Hal ini haruslah diluruskan terhadap pemikiran masyarakat bahwa pembiayaan murabahah pada perbankan syariah memiliki skema yang berbeda dengan perbankan konvensional. Selain memiliki skema yang berbeda, perbankan syariah memiliki kebijakan dan sistem yang berlandaskan syariat Islam yaitu Al-Qur'an dan Hadits.

Perjanjian pada akad murabahah merupakan akad jual beli dimana harga jual dihitung dari harga perolehan ditambah margin yang telah disepakati diawal oleh mitra dengan perbankan syariah. Margin yang digunakan sesuai dengan perhitungan yang telah ditetapkan oleh perbankan syariah, artinya tidak ada patokan pasti dalam menentukan margin pembiayaan murabahah. Menurut penelitian Rahma, (2016) perbankan syariah memilih untuk menggunakan metode anuitas dalam penetapan margin pembiayaan murabahah. Pada metode anuitas perbankan akan menetapkan margin yang lebih besar diawal bulan pertama 
dan akan menurun tingkat marginnya pada akhir pembayaran (Wulandari et al., 2015). Margin pembiayaan murabahah memiliki nilai yang lebih besar dibandingkan dengan suku bunga pasar atau inflasi. Hal ini berdampak pada msyarakat yang berspekulasi negatif tentang perbankan syariah. Pada kenyataannya perbankan syariah menggunakan nilai margin lebih besar karena untuk mengantisipasi adanya kenaikan suku bunga pasar dan inflasi. Margin pembiayaan murabahah ditetapkan oleh tim Asset and Liability Management Commite (ALCO). Tim ALCO bertugas untuk merekomendasikan, mengusulkan, dan memberikan saran dalam menetapkan margin. Terdapat dua faktor dalam menentukan margin yaitu faktor internal berupa kebijakan operasional didalam perusahaan yang digunakan bank syariah seperti FDR dan Return On Assets (ROA) dan faktor eksternal seperti inflasi, BI 7 day repo rate, dan nilai tukar (Asri, 2020).

Dilihat dari krisis ekonomi yang terjadi pada tahun 1998 menunjukkan bahwa inflasi memiliki pengaruh terhadap perbankan di Indonesia. Inflasi terjadi ketika suatu barang dan jasa secara umum mengalami kenaikan terus menerus dalam jangka waktu tertemtu (Satya, 2013). Inflasi yang terjadi akan memiliki dampak terhadapa menurunnya permintaan terhadap konsumsi dan jasa. Penyebab terjadinya inflasi adalah demand pull inflation yaitu meningkatnya permintaan masyarakat naman tidak diimbangi dengan output dan cost push inflatioan yaitu kenaikan biaya produksi yang mengakibatkan naiknya harga jual (Dwijayanty, 2017). Solusi yang dilakukan oleh perbankan dalam menghadapi inflasi adalah pemerintah akan mengeluarkan kebijakan moneter dengan cara menaikkan suku bunga Bank Indonesia yang berakibat terhadap kanaikan suku bunga pinjaman bank (Nadya et al., 2020).

Sejak tanggal 19 Agustus 2016 Bank Indonesia memiliki kebijakan baru dalam penguatan operasi moneter yaitu mengubah suku bunga $\mathrm{BI}$ Rate menjadi BI 7 Day Repo Rate (BI7DRR). BI7DRR merupakan kebijakan baru yang dapat scera langsung mempengaruhi terhadap pasar uang, perbankan dan sektor riil. Tujuan utama BI7DRR sebagai penguat dan acuan dalam kegiatan pasar keuangan, memperkuat efektivitas pergerakan 
suku bunga pasar uang dan suku bunga perbankan, dan membentuk pasar uang yang dikhususkan pada transaksi suku bunga Pasar Uang Antar Bank (PAUB) dengan tenor 3-12 bulan (www.bi.go.id).

Kesuksesan dalam sistem keuangan dapat dilihat dari pengoptimalan dalam pengalokasian sumber daya perekonomian dan meningkatkan pertumbuhan ekonomi (Ichsan, 2017). Guncangan tersebut dapat disebabkan oleh fluktuasi nilai tukar salah satunya. Nilai tukar yang melemah akan berpengaruh terhadap peningkatan Non Performing Financing (NPF) dan menyebabkan krisis likuiditas pada kegiatan perbankan syariah dan perbankan konvensional. Nilai tukar memiliki peran yang sangat penting karena pergerakannya dapat berpengaruh terhadap stabilitas ekonomi. Selain itu, nilai tukar juga berperan dalam mempermudah transaksi dengan dunia internasional (Sulistyawati et al., 2020). Nilai tukar yang selalu mengalami fluktuasi akan berdampak pada permodalan perbankan syariah, akibatnya akan menghambat sistem permodalan pembiayaan yang dilakukan perbankan syariah (Ichsan, 2017). Menguatnya nilai tukar akan membuat masyarakat menarik uang dari perbankan dan menukar dengan uang asing. Hal ini akan menyebabkan perbankan mengalami kesulitan dalam kegiatan menyalurkan dananya kepada masyarakat. Apabila nilai tukar mengalami penurunan maka pembiayaan murabahah akan stabil atau meningkat. Hal tersebut dikarenakan ketikan nilai tukar mengalami depresiasi maka produk dalam negeri akan berkompetisi untuk meningkatkan ekspor (Ichsan, 2017).

\section{TINJAUAN PUSTAKA}

\section{Perbankan Syariah}

Perbankan syariah adalah suatu lembaga yang mencakup bank syariah dan unit usaha syariah, kegiatan usaha, dan cara maupun proses dalam melaksanakan kegiatan usaha tersebut sesuai dengan UndangUndang No. 21 Tahun 2008 (Ismail, 2011). Menurut Rahma, (2016) perbankan syariah merupakan kegiatan usaha dalam menghimpun dan menyalurkan dana kepada masyarakat. Perbankan syariah dalam menjalan kegiatannya berdasar kepada prinsip syariah. Prinsip syariah merupakan 
landasan hukum islam berupa fatwa-fatwa yang dikeluarkan lembaga penetapan fatwa dibidang syariah (Werdi Apriyanti, 2018). Menurut jenisnya perbankan syariah terdiri dari Bank Umum Syariah (BUS), Unit Usaha Syariah (UUS), dan Bank Pembiayaan Rakyat Syariah (BPRS) (Ismail, 2011).

\section{Pembiayaan Murabahah}

Murabahah adalah akad jual beli atas barang dimana penjual akan menyebutkan harga kepada pembeli dengan syarat dan ketentuan yang telah disepakati bersama (Ismail, 2011). Murabahah merupakan produk perbankan syariah yang berbasis terhadap jual beli dan paling banyak digunakan di kegiatan usaha bank syariah. Ahli ekonomi dan keuangan islam menyatakan bahwa tidak menganjurkan nasabah untuk melakukan pembiayaan murabahah, akan tetapi menggunakan pembiayaan profitloss sharing seperti mudharabah atau musharakah. Namun perbankan syariah saat ini lebih memilih untuk menggunakan kegiatan usaha murabahah karena dapat menjadi bisnis usaha.

\section{Margin}

Pendapatan yang diterima oleh perbankan syariah melalui prinsip pembiayaan jual beli disebut dengan pendapatan margin (Rimadhani \& Erza, 2011). Margin merupakan keuntungan yang diterima oleh bank syariah yang dibayarkan nasabah sebagai hasil atas kegiatan jual beli yang dilakukan oleh kedua belah pihak (Ekawati \& Shofawati, 2019). Pembiayaan margin dilakukan dengan menggunakan lump sum atau menggunakan penetapan rasio tertentu terhadap harga beli barang. Pembayaran margin dilakukan dalam satu kali transaksi dan tidak boleh melakukan pembayaran dengan cara berjangka atau setiap bulan (Wangsawidjaja, 2012).

\section{Inflasi}

Inflasi terjadi ketika suatu barang dan jasa secara umum mengalami kenaikan terus menerus dalam jangka waktu tertentu (www.bi.go.id). Definisi lain mengatakan bahwa inflasi terjadi ketika suatu perekonomian mengalami kenaikan harga secara cepat yang akan berdampak terhadap 
turunnya daya beli masyarakat. Selain itu, dapat dilihat dari menurunnya tabungan dan atau investasi akibat kenaikan tingkat konsumsi sehinga sedikit dari masyarakat untuk menabung dalam jangka panjang (Purnamasari \& Musdholifah, 2016).

\section{BI 7 Day Repo Rate}

$\mathrm{BI}$ rate adalah kebijakan suku bunga moneter yang ditetapkan oleh Bank Indonesia yang diumumkan kepada masyarakat. Pengumuman kebijakan BI rate dilakukan oleh Dewan Gubernur Bank Indonesia melalui rapat bulanan melalui pengelolaan likuiditas (liquidity management) dipasar uang. Bank Indonesia memiliki kebijakan moneter dalam menetapkan sasaran-sasaran moneter yang bertujuan menjaga laju inflasi pemerintah (Ma'arif \& Budiyono, 2015). Menurut Satya, (2013) suku bunga merupakan harga keguanaan uang yang digunakan pada saat ini dan akan dikembalikan pada saat mendatang.

\section{Nilai Tukar}

Nilai tukar adalah suatu nilai yang digunakan untuk menunjukkan nilai dari mata uang dalam negeri terhadap nilai mata uang luar negeri (Purnamasari \& Musdholifah, 2016). Nilai tukar berguna untuk mempresentasikan tingkat harga dari satu mata uang terhadap mata uang lain (Dwijayanty, 2017). Peningkatan valuta asing dapat terjadi jika impor barang dan jasa atau ekspor mengalami peningkatan. Selain itu peningkatan juga terjadi apabila modal yang didapat lebih tinggi dari pada modal yang dikeluarkan. Nilai tukar memiliki dua sistem utama Internasional yang digunakan yaitu nilai tukar tetap (fixed exchange rate) adalah sistem nilai tukar mata uang yang bernilai tetap dari waktu ke waktu dengan nilai mata uang asing negara lain dan harga emas tidak mengalami perubahan. Kedua, nilai tukar fleksibel (flexible exchange rate) yaitu ketika bank sentral membiarkan nilai tukar untuk bergerak secara bebas (Sulistyawati et al., 2020).

\section{METODE PENELITIAN}

Jenis penelitian yang digunakan adalah kuantitatif dengan pendekeatan deskriptif. Data yang digunakan adalah data runtun waktu 
(time series) diambil dari laporan statistikan Bank Indonesia (BI) dengan skala satu bulan selama periode 2016-2020. Populasi yang digunakan adalah perbankan syariah di Indonesia, dengan menggunakan teknik purposive sampling didapat 2 sampel penelitian yaitu, Bank Umum Syariah (BUS) dan Unit Usaha Syariah (UUS). Teknik mengumpulkan data menggunakan field research yaitu mengambil data dari laporan yang diterbitkan di website Bank Indonesia (BI) dan Otoritas Jasa Keuangan (OJK) dan library research yaitu mengumpulkan dan melengkapi penelitian dengan cara membaca, mengamati, dan menganalisis dari literasi terkait. Variabel dalam penelitian ini diklasifikasikan menjadi variabel independen dan variabel dependen. Variabel independen yaitu Inflasi $\left(\mathrm{X}_{1}\right)$, BI 7 Day Repo Rate $\left(\mathrm{X}_{2}\right)$ dan Nilai Tukar $\left(\mathrm{X}_{3}\right)$ sedangkan variabel dependen adalah Margin Pembiayaan Murabahah (Y).

\section{HASIL DAN PEMBAHASAN}

\section{Hasil Uji Statistik}

Variabel yang digunakan dalam penelitian ini adalah variabel independen yaitu inflasi $\left(X_{1}\right)$, BI 7 day repo rate $\left(X_{2}\right)$ dan nilai tukar $\left(X_{3}\right)$. Untuk variabel dependen, yaitu margin pembiayaan murabahah $(\mathrm{Y})$. Data statistik dekriptif masing-masing variabel penelitian, disajikan pada tabel berikut :

\section{Hasil Uji Statistik Deskriptif}

\begin{tabular}{|c|c|c|c|c|}
\hline Statistik & $\begin{array}{c}\text { Pendapatan Margin } \\
\text { Pembiayaan } \\
\text { Murabahah }\end{array}$ & Inflasi & $\begin{array}{c}\text { BI 7 Day } \\
\text { Repo Rate }\end{array}$ & $\begin{array}{c}\text { Nilai } \\
\text { Tukar }\end{array}$ \\
\hline Minimum & 1.529 & 1,32 & 3,75 & 13.063 \\
\hline Maksimum & 21.551 & 4,37 & 6 & 16.448 \\
\hline Mean & 11.156 & 3,03 & 4,88 & 14.096 \\
\hline $\begin{array}{c}\text { Standar } \\
\text { Deviasi }\end{array}$ & $5.755,6$ & 0,72 & 0,68 & 647,38 \\
\hline
\end{tabular}

Sumber: Data diolah

Hasil uji statistik pada tabel menunjukkan nilai tertinggi pada margin pembiayaan murabahah adalah 21.551 milyar dan nilai terendah sebesar 1.529 milyar. Berdasarkan data tersebut dapat dilihat bahwa nilai minimum pada pembiayaan murabahah berada ditahun 2017 dan nilai maksimum terdapat pada tahun 2019. Hasil analisis diatas diketahui bahwa margin 
pembiayaan murabahah mengalami perubahan positif dengan rata-rata sebesar 11.156 milyar. Hal ini menunjukkan bahwa selama periode 20162020 perbankan syariah memiliki pendapatan margin pembiayaan murabahah yang cukup baik. Artinya, masyarakat banyak menggunakan produk pembiayaan murabahah dalam melakukan pembiayaan.

Hasil uji statistik variabel inflasi menunjukkan bahwa nilai minimum sebesar $1,32 \%$ dan nilai maksimum adalah sebesar $4,37 \%$. Dari data tersebut diketahui bahwa nilai minimum inflasi berada pada tahun 2020 bulan Agustus dan nilai tertinggi inflasi berada pada tahun 2017 bulan Juni. Nilai rata-rata variabel inflasi adalah diatas 3,03\%. Artinya, ketika inflasi berada pada titik maksimal akan menyebabkan selera atau kemampuan masyarakat menjadi menurun, sehingga hal ini akan berdampak terhadap permintaan pembiayaan murabahah.

Hasil uji statistik pada variabel BI 7 Day Repo Rate menunjukkan bahwa nilai paling rendah yaitu $3,75 \%$ dan nilai yang paling besar adalah $6 \%$. Dari data tersebut diketahui bahwa nilai minimum berada pada tahun 2020 bulan November dan Desember, sedangkan nilai maksimum berada pada tahun 2018 bulan November dan Desember dan 2019 bulan Januari - Juni. Nilai rata-rata variabel BI 7 day repo rate adalah diatas 4,88\%. Artinya, ketika BI 7 Day Repo Rate berada pada titik maksimal maka permintaan masyarakat terhadap pembiayaan akan mengalami kenaikan, sehingga permintaan pembiayaan murabahah sebagai pembiayaan alternatif mengalami kenaikan.

Hasil uji statistik pada variabel nilai tukar menunjukkan bahwa nilai minimum sebesar 13.603 rupiah dengan nilai maksimum 16.448 rupiah. Nilai minimum berada pada tahun 2016 bulan september dan nilai maksimum berada pada tahun 2020 bulan maret. Nilai rata-rata variabel nilai tukar diatas 14.096 rupiah. Artinya, ketika nilai tukar berada pada titik maksimum kemampuan masyarakat akan mengalami penurunan, sehingga akan mengakibatkan penurunan terhadap pembiayaan murabahah. 


\section{Hasil Analisis Regresi Linier Berganda}

Hasil uji regresi linier berganda dengan menggunakan eviews 10 ditampilkan pada tabel berikut:

\section{Hasil Uji Regresi Linier Berganda}

\begin{tabular}{|l|c|c|}
\hline $\begin{array}{l}\text { Dependen } \\
\text { Variabel }\end{array}$ & \multicolumn{1}{l}{$\begin{array}{l}\text { Margin } \\
\text { Pembiayaan }\end{array}$} & Murabahah \\
\hline \multicolumn{1}{|c|}{ Variabel } & Koefisien & Prob. \\
\hline C & 512340,4 & 0,0000 \\
\hline Inflasi & $-22662,22$ & 0,0000 \\
\hline $\begin{array}{l}\text { BI 7 Day Repo } \\
\text { Rate }\end{array}$ & $-6739,61$ & 0,1441 \\
\hline Nilai Tukar & $-28,18930$ & 0,0000 \\
\hline F-Statistik & 61,68425 & \\
\hline Prob (F-Statistik) & 0,000000 & \\
\hline
\end{tabular}

Sumber: Data diolah

Dari hasil uji regresi linier berganda pada tabel di atas, maka dapat ditarik persamaan regresi sebagai berikut:

Margin Pembiayaan Murabahah $=512340,4-2262,22-6739,61-28,18930$

Dari persamaan regresi linier berganda dapat diketahui bahwa apabila nilai konstanta sebesar 512340,4 dapat diartikan yaitu ketika variabel inflasi, BI 7 day repo rate, dan nilai tukar memiliki nilai konstan (tidak mengalami perubahan) diasumsikan 0 , maka nilai margin pembiayaan murabahah sebesar 512340,4.

Koefisien pada variabel inflasi $\left(X_{1}\right)$ memiliki nilai $-2262,22$ dan nilai probabilitas sebesar $0,0000<0,05$, artinya variabel inflasi berpengaruh negatif signifikan terhadap variabel margin pembiayaan murabahah. Ketika margin pembiayaan murabahah mengalami kenaikan sebesar $1 \%$, maka akan menurunkan margin pembiayaan murabahah sebesar 226,222\%.

Koefisien pada variabel $\mathrm{BI} 7$ day repo rate $\left(\mathrm{X}_{2}\right)$ memiliki nilai sebesar $-6739,61$ dan nilai probabilitas $0,1441>0,05$. Artinya variabel $\mathrm{BI} 7$ day repo rate tidak berpengaruh signifikan terhadap margin pembiayaan murabahah.

Koefisien pada variabel nilai tukar $\left(X_{3}\right)$ adalah -28,18930 dengan probabilitas sebesar $0,0000<0,05$. Artinya variabel nilai tukar berpengaruh 
negatif signifikan terhadap margin pembiayaan murabahah. Dapat dikatakan bahwa ketika nilai tukar mengalami kenaikan sebesar 1\% akan menyebabkan penurunan terhadap margin pembiayaan murabahah sebesar $2818,93 \%$.

\section{Uji Statistik F (Uji Simultan)}

Adapun hasil uji F statistik, ditampilkan pada tabel di bawah ini:

\section{Hasil Uji Statistik F}

\begin{tabular}{|c|c|}
\hline F-Statistic & 61,68425 \\
\hline Prob (F-Statistic) & 0,000000 \\
\hline
\end{tabular}

Sumber: data diolah

Hasil uji statistik pada tabel di atas dapat dilihat bahwa nilai dari Prob (F-Statistic) sebesar 0,000000 $<0,05$, artinya variabel inflasi, BI 7 day repo rate, dan nilai tukar berpengaruh secara simultan (bersama-sama) terhadap variabel margin pembiayaan murabahah.

\section{Uji Statistik T (Uji Parsial)}

Adapun hasil uji T statistik, ditampilkan pada tabel di bawah ini:

\begin{tabular}{|c|c|c|c|} 
Hasil Uji Statistik T \\
\hline Variabel & Koefisien & T-Statistic & Prob. \\
\hline Inflasi & $-22662,22$ & -6.112244 & 0,0000 \\
\hline $\begin{array}{c}\text { BI 7 Day Repo } \\
\text { Rate }\end{array}$ & $-6739,610$ & $-1,480906$ & 0,1441 \\
\hline Nilai Tukar & $-28,18930$ & $-9,379073$ & 0,0000 \\
\hline
\end{tabular}

\section{Sumber: Data diolah}

Dari hasil uji T pada tabel di atas, diketahui bahwa variabel inflasi terhadap margin pembiayaan murabahah mendapatkan koefisien regresi sebesar -22662,22 dan nilai t-statistic sebesar -6,112244 dengan nilai probabilitas sebesar 0,0000. Data tersebut menunjukkan bahwa koefisien bernilai negatif dan nilai probabilitas kurang dari 0,05 , artinya variabel inflasi secara parsial berpengaruh negatif signifikan terhadap margin pembiayaan murabahah.

Adapun variabel $\mathrm{BI} 7$ day repo rate terhadap margin pembiayaan murabahah memiliki koefisien $-6739,610$ dan nilai t-statistic sebesar 1,480906 dengan nilai probabilitas sebesar 0,1441. Dari hasil pengujian tersebut didapatkan koefisien bersifat negatif dan probabilitas lebih dari 
0,05. Artinya variabel BI 7 day repo rate secara parsial berpengaruh tidak signifikan terhadap margin pembiayaan murabahah.

Sedangkan variabel nilai tukar terhadap margin pembiayaan murabahah memiliki koefisien sebesar -28,18930 dan t-statistic sebesar -9,379073 dengan nilai probabilitas sebesar 0,0000. Dari hasil pengujian data menunjukkan bahwa koefisien bersifat negatif dengan probabilitas kurang dari 0,05 . Artinya variabel nilai tukar secara parsial berpengaruh negatif signifikan terhadap margin pembiayaan murabahah.

\section{PEMBAHASAN}

\section{Pengaruh Inflasi terhadap Margin Pembiayaan Murabahah}

Berdasarkan hasil uji statistik di atas, dijelaskan bahwa variabel inflasi memiliki nilai probabilitas 0,0000 < 0,05 dengan koefisien -22662,22. Dapat dikatakan bahwa variabel inflasi berpengaruh negatif dan signifikan terhadap margin pembiayaan murabahah. Artinya, semakin besar inflasi yang ditetapkan maka margin pembiayaan murabahah akan semakin turun. Sebaliknya, semakin rendah inflasi maka penetapan margin pembiayaan murabahah akan semakin tinggi.

Ketika inflasi tinggi akan menyebabkan kenaikan harga secara terus menerus, sehingga perekonomianpun akan menjadi buruk. Masyarakat akan enggan bekerja karena itu akan sia-sia yang disebabkan nilai mata uang yang terus menurun. Hal itu akan berdampak terhadap kemampuan dari masyarakat itu sendiri, sehingga menyebabkan permintaan terhadap pembiayaan murabahah mengalamai penurunan (Jihad \& Hosen, 2009).

\section{Pengaruh BI 7 Day Repo Rate terhadap Margin Pembiayaan Murabahah}

Berdasarkan hasil uji statistik di atas, dijelaskan bahwa variabel BI 7 day repo rate memiliki nilai probabilitas sebesar $0,1441>0,005$ dengan koefisien $-6739,610$. Hasil ini menyatakan bahwa variabel $\mathrm{BI} 7$ day repo rate tidak berpengaruh signifikan terhadap margin pembiayaan murabahah.

Hasil penelitian menjelaskan bahwa perbankan syariah tidak menggunakan BI7DRR sebagai patokan margin pembiayaan murabahah. Perbankan syariah merupakan lembaga keuangan yang berlandaskan 
kepada syariat Islam dan tidak mengimplementasikan sistem riba didalam praktiknya. Dalam menetapkan margin perbankan syariah mempunyai perhitungan tersendiri yang dilakukan oleh tim ALCO (Asset and Liability Management Commite). Besar kecilnya margin yang digunakan didalam perbankan syariah akan berdampak terhadap bank itu sendiri. Ketika perbankan syariah menaikkan margin lebih tinggi dari bank konvensional secara tidak langsung akan menaikkan tingkat inflasi. (Setyaji, 2018).

\section{Pengaruh Nilai Tukar terhadap Margin Pembiayaan Murabahah}

Berdasarkan hasil uji statistik di atas, dijelaskan bahwa variabel nilai tukar memiliki nilai probabilitas sebesar 0,000 0,05 dengan koefisien 28,18930 . Dapat dikatakan bahwa variabel nilai tukar berpengaruh negatif signifikan terhadap margin pembiayaan murabahah.

Ketika nilai tukar rupiah terhadap dolar tinggi, maka akan berakibat terhadap naiknya biaya produksi dan jasa, sehingga akan berakibat terhadap kenaikan harga jual objek. Naiknya harga barang dan jasa akan berdampak terhadap turunnya kemampuan konsumtif masyarakat. Hal ini akan berdampak terhadap permintaan dan margin pembiayaan murabahah (Jihad \& Hosen, 2009).

Pengaruh Inflasi, Bi 7 Day Repo Rate, dan Nilai Tukar terhadap

\section{Margin Pembiayaan Murabahah}

Berdasarkan uji statistik $\mathrm{F}$ (uji simultan) yang dilakukan, diperoleh hasil probabilitas (F-Statistic) sebesar 0,000000. Dilihat dari hasil uji tersebut dapat dikatakan bahwa nilai probabilitas kurang dari nilai signifikansi yaitu 0,05, artinya ketiga variabel independen yaitu inflasi, BI 7 day repo rate, dan nilai tukar secara simultan (bersama-sama) berpengaruh terhadap Margin Pembiayaan Murabahah Perbankan Syariah di Indonesia.

\section{KESIMPULAN}

Berdasarkan hasil analisis data dan pembahasan yang telah dijelaskan sebelumnya, mengenai pengaruh fee based income, spread bagi hasil dan financing to deposit ratio terhadap profitabilitas, maka dapat ditarik kesimpulan sebagai berikut : 
1. Variabel inflasi berpengaruh negatif signifikan terhadap margin pembiayaan murabahah Perbankan Syariah di Indonesia.

2. Variabel BI 7 day repo rate tidak berpengaruh signifikan terhadap margin pembiayaan murabahah Perbankan Syariah di Indonesia.

3. Variabel nilai tukar berpengaruh negatif signifikan terhadap margin pembiayaan murabahah Perbankan Syariah di Indonesia.

4. Vaiabel inflasi, BI 7 day repo rate, dan nilai tukar secara simultan (bersama-sama) berpengaruh signifikan terhadap margin pembiayaan murabahah Perbankan Syariah di Indonesia.

\section{SARAN}

Berdasarkan hasil analisis dari penelitian diatas, penulis memberikan saran-saran sebagai berikut:

1. Untuk penelitian berikutnya lebih baik untuk menambahkan periode penelitian dan menambah sampel penelitian yang lebih banyak lagi, agar hasil yang didapatkan lebih signifikan. Selain itu, penelitian selanjutnya dapat menambahkan variabel lain yang dapat mempengaruhi margin pembiayaan murabahah.

2. Diharapkan bagi masyarakat umum setelah membaca penelitian ini dapat memberikan pemahaman tentang perbedaan konsep dan implementasi dari perbankan syariah dan perbankan konvensional, serta dapat mengkaji kapan dan waktu yang tepat dalam melakukan pembiayaan murabahah.

3. Bagi perbankan syariah melakukan inovasi terhadap produkproduk perbankan syariah sehingga mampu bersaing dengan lembaga keuangan lainnya. Variabel yang tidak berpengaruh seperti BI 7 Day Repo Rate mengindikasikan bahwa perbankan syariah tidak menggunakan variabel tersebut dalam penetapan margin pembiayaan murabahah.

\section{DAFTAR PUSTAKA}

Anshori, A. G. (2009). Perbankan Syariah Di Indonesia. Gadjah Mada University Press.

Asri, A. R. (2020). Pengaruh Financing To Deposit Ratio ( Fdr ), Return On Asset ( Roa ), Tingkat Suku Bunga Bank Indonesia ( Bi Rate ), Dan 
Inflasi Terhadap Margin Murabahah Pada Perbankan Syariah Di Indonesia. Jurnal IImiah.

Dwijayanty, R. (2017). Dampak Variabel Makro Ekonomi Terhadap Permintaan Pembiayaan Murabahah Perbankan Syariah. Jurnal Riset Akuntansi Dan Keuangan, 5(1), 1349-1356.

Ekawati, K., \& Shofawati, A. (2019). Faktor-Faktor Yang Mempengaruhi Tingkat Margin Murabahah Pada Industri Perbankan Syariah Periode 2012-2017. Jurnal Ekonomi Dan Bisnis Islam (Journal of Islamic Economics and Business), 5(1), 50.

Ichsan, N. (2017). Analisis Pengaruh Ekonomi Makro Dan Stabilitas Perbankan Syariah Terhadap Pembiayaan Produktif Dan Konsumtif Pada Perbankan Syariah Di Indonesia Periode Januari 2010 - Maret 2017. 12(23), 68-83.

Ismail. (2011). Perbankan Syariah. Prenadamedia Group.

Jihad, \& Hosen, M. N. (2009). Faktor-Faktor Yang Mempengaruhi Permintaan Pembiayaan Murabahah Bank Syariah Di Indonesia (Periode Januari 2004-Desember 2008). Dikta Ekonomi, 6(2).

Ma'arif, S. M., \& Budiyono, I. (2015). Analisis Pengaruh Dana Pihak Ketiga, Sertifikat Bank Indonesia Syariah, BI Rate, Dan Inflasi Terhadap Pembiayaan Murabahah Perbankan Syariah Di Indonesia Periode 2006-2014. Jurnal Sains Ekonomi Dan Perbankan Syariah, 5(1), 1-15.

Nadya, A., Tanjung, M., \& Sugianto. (2020). Analisis Faktor Eksternal Dan Internal Terhadap Pembiayaan Pada Bank Umum Syariah Yang Terdaftar Di OJK. Journal Of Islamic Economics and Finance Studies, 1(2), 153-172.

Purnamasari, A. E. K. A., \& Musdholifah. (2016). Analisis Faktor Eksternal Dan Internal Bank Teradap Pembiayaan Bank Syariah Di Indonesia Periode 2012-2015. Jurnal Bisnis Dan Manajemen, 9(1).

Rahma, Y. (2016). Faktor-Faktor Yang Mempengaruhi Margin Murabahah Bank Syariah Di Indonesia. Akuntabilitas, 9(1), 43-54.

Rimadhani, M., \& Erza, O. (2011). Analisis Variabel-Variabel Yang Mempengaruhi Pembiayaan Murabahah Pada Bank Syariah Mandiri Periode 2008.01-2011.12. 12(1), 27-52.

Satya, K. (2013). Faktor-Faktor Yang Mempengaruhi Penetapan Margin Murabahah Pembiayaan Konsumtif Di Bank KALTIM Syariah. Ekonomika-Bisnis, 4(2), 151-169.

Setyaji, A. K. (2018). Analisis faktor penjelas pendapatan margin. Jurnal Fakultas Ekonomi Islam, 559-568.

Sjahdeni, S. R. (2014). Perbankan Syariah Produk-Produk Dan AspekAspek Hukumnya. Prenadamedia Group.

Sulistyawati, A. I., Santoso, A., \& Kurniawan, R. (2020). Penelusuran faktor pengaruh pembiayaan Murabahah. 6(2), 83-96.

Utama, A. S. (2020). Perkembangan Perbankan Syariah Di Indonesia. Journal Soematra Law Review, 2(3), 290-298.

Wangsawidjaja. (2012). Pembiayaan Bank Syariah. PT Gramedia.

Werdi Apriyanti, H. (2018). Perkembangan Industri Perbankan Syariah Di Indonesia: Analisis Peluang Dan Tantangan. Maksimum Media 
Akuntansi, 8(1), 16.

Wulandari, P., Iwani, N., Putri, S., Kassim, S., \& Sulung, L. A. (2015). Contract agreement model for murabahah financing in Indonesia Islamic banking. International Journal of Islamic and Middle Eastern Finance and Management, 9(2), 190-204. 